\title{
INTRODUCTION
}

\section{BREXIT: WE'LL CROSS THAT BRIDGE WHEN WE COME TO IT}

\section{Rana İZCI CONNELLY* James CONNELLY**}

BBC Radio 4 recently broadcast a three-part series called 'Brexit: A Guide for the perplexed'. The result of the Referendum was indeed perplexing. Many Leave supporters could not believe what had happened: both sides had expected Remain to win, and many voters did not go to the polls, because they thought that a victory for Remain was assured. When the dust settled, explanations of why and how it happened followed each other with bewildering and overlapping speed. It was, however, not only the British public and politicians who seemed to have been caught off guard by the result. The entire world seemed to be puzzled. From 'Brexiteers' to 'backstop' plans, various new words and phrases have been coined to help in understanding the situation, the attitude of different parties, and the technicalities of the official negotiation process. What is more perplexing however, with less than a year before the United Kingdom (UK) officially leaves the European Union, is the uncertainty and confusion that reign in parliamentary discussions and everyday politics about the withdrawal negotiations and the route for the UK outside the EU. This situation especially baffles some zealous Brexiteers who somehow thought that the UK and EU would and could immediately sever all their ties the morning after the result was announced, as though it were a matter of saying goodbye to a brief encounter rather than divorcing a spouse of some forty-three years. In all this, it would be fair to argue that the dynamics of the referendum campaign contributed greatly to the general confusion we now see.

As was to be expected, from the very beginning there was fierce competition to frame the referendum debate between the opposing camps. The Remain campaign underlined the negative economic scenarios that the UK might have to face if it left the EU. It stressed the loss of jobs and competitiveness, pointed out the complicated technicalities of a possible divorce from the EU, the size of

\footnotetext{
*Ph.D, e-mail: ranaizci@marmara.edu.tr.

** Professor of Political Theory, Department of Politics, University of Hull, e-mail: j.connelly@hull.ac.uk.
} 
the divorce bill, the uncertain future for British citizens living in EU countries, the issue of Gibraltar, the future of the Good Friday agreement, long queues for customs checks at Dover, and asked whether Brexit was worth pursuing. On the other hand, the Leave campaign envisioned a better future outside the EU. They emphasized the financial advantages that could be gained through leaving the EU and claimed that the Remain campaign was running 'a project fear'. Immigration was at the centre of the stage in all discussions. Brexiteers argued that uncontrolled immigration was the main cause of unemployment, housing problems, lack of good schooling, the overwhelming of the national health service, social problems and crime. Thus, they concluded, the UK had to take control of its own borders as well as its economy. 'Taking back control' was (and still is) their number one mantra. Even though most immigration issues were related to the numbers of Eastern and Central European EU citizens, Brexiteers played another card to support their point: Turkey. This embodied a double claim to the effect that Turkish membership might contribute to the scale of migration and that the UK did not have a veto to block Turkish membership. Even though the UK has long been known as a supporter of Turkish accession, these claims created another tension in EU-Turkey relations. One can assume that such arguments were put forward to challenge the Cameron government, to create the impression that the UK had no power to shape European Integration and that everything was imposed from 'Brussels'. Nevertheless, one can also reflect upon the fear of migration, identity problems and economic disparities in the UK. While acknowledging the existence of the problems within the current immigration system and past mistakes, Remainers maintained that migrants were not liabilities to British society and that, on the contrary, they contributed significantly to the prosperity and well-being of the country. Remainers emphasized the importance of the migrant workforce in the health sector as well as in agriculture, higher education, financial services and hospitality. However, the Syrian refugee crisis and refugees from Africa exacerbated the controversy over immigration and control over borders. In the end, it was all fanned into a flame war.

Since the referendum was regarded - certainly by Brexiteers (and Remainers who felt they had to accept the result) - as the 'will of people', the issue of the tone and register of political communication and the language of Brexit in everyday life gained even more significance. 'Neutral' broadcasting by the $\mathrm{BBC}$, the digital battle in the social media, and sensational headlines in the tabloid press sometimes turned the debates into a pantomime and at other times into tedious and vapid empty talk. Belatedly, many commentators concluded that the Brexit side had won the case in the popular mind even before the start of the campaign. Certainly, the ways in which the UK's EU membership and the EU itself were narrated in the media starkly revealed the weakest points in current British political culture and the minefields lurking in the socio- 
economic history of the country. There is a broad range of issues to be discussed within this framework: the role and meaning of Parliament for British citizens, devolution, regulatory control and hyper-liberals, losers from globalisation and re-distributive policies, European identities and the concept of sovereignty, to name only a few.

Recent global economic crises have intensified increasing socio-economic inequality and dissatisfaction with living standards around the world and reshaped public opinion about market-state-society links. Economic disparities have not only challenged political trust and cultural values but also underlined the lack of (and need for) transparency. In different parts of the world, we have witnessed the rise of unexpected political actors, widespread public protests and the emergence of various forms of direct political engagement. Such dissatisfaction has, in the UK, manifested itself in the form of scepticism about EU membership. In her article in this special issue, Eunice Goes investigates how British public's dissatisfaction with the economy affected their electoral preferences and hence their referendum vote. Simon Lee analyses the visions of sovereignty, market values and democracy in relation to the politics of Brexit; and James Connelly inquires into the relationship between intra-party friction, general elections, and the holding and framing of referendums in the UK since 1975.

During the campaigning period, party politics also underwent some unexpected turns. Traditional party lines were challenged, loyalties were questioned and became fluid, party leaders were at odds with their close colleagues and important figures in their own parties. The Labour and Conservative parties especially experienced sour and tempestuous times. However, such conflicts of opinion were not limited to the Parliamentary parties and their grass roots. Voters in general also disagreed with their leaders and parties. Yet, after the referendum, party politics dramatically resurfaced and resoundingly hit the headlines again, with echoes of Greek tragedy, Icelandic Sagas and occasionally Whitehall farce. To start with, the Prime Minister resigned and the Conservative Party found itself plunged into a leadership struggle. Then the United Kingdom Independence Party (UKIP) seemed to lose its raison d'etre and immediately faced stormy internal conflicts. Resignations, power-grabbing plots, unusual alliances, party leader changes, a new prime minister and a snap general election followed each other in remarkably short succession, affecting all the parties in one way or another and leaving both participants and observers gasping for breath. Every hour brought a new surprise and frequently the pace of events made it almost impossible to comprehend what was going on. It was astonishingly eventful and painfully entertaining: one could almost hear the cry of 'if only somebody could tell us all what Brexit means and how to achieve it!' 
Since the 1970s, the issue of European Integration has been a hot topic in British politics, generally leading to the ruin (sometimes gradually, sometimes immediately) of whoever tried to manipulate UK-EU relations for domestic gains or power politics within their party. Many politicians have come to grief over Europe-related matters: Margaret Thatcher and David Cameron are the only the most well-known names in a long list. Politicians from both the Labour Party and the Conservative Party have changed their opinions about the EU over this period. Not only individual politicians but both main political parties have taken anti and pro European attitudes at different times too, sometimes as a protest against the government of the day or as part of their reading of the trend of European integration. Whatever the case, it seems that Europe as an ideal never registered in most of the British politicians' and bureaucrats' vision. A side effect of this is that many (perhaps most) MEPs were invisible not only to the British public but also to their own parties.

The EU's immediate response to the referendum result was to pressure the UK to start the Brexit process as soon as possible. However, the EU also stated that the UK was still a member until the departure process was finalised. Despite their statement, British Eurocrats felt that their power and authority to be immediately diminished; as an example, academics, research bodies and universities found that participation in many EU funded research projects became problematic and uncertain. Not only the presidents of EU institutions but also the heads of states and governments of member state expressed regret that Britain would leave the Union. Nevertheless, their message was clear: solidarity in action to prevent future Brexit-like situations. Phrases such as 'no special treatment' and 'there will be consequences' were repeated on various occasions by EU leaders.

The UK triggered Article 50 on 29 March 2017: this means that the UK will leave the EU (with or without agreement) on 29 March 2019. The EU and its member states at the moment do not seem willing to allow extra time for the negotiations. The draft withdrawal agreement between the EU and the UK Government was published in March 2018. Later in the same month, agreement in principle to a transitional or implementation period was announced. This stipulates that, following formal withdrawal in March 2019, the UK will retain access to the internal market and Customs Union until 31 December 2020. The precise details of this agreement remain to be determined. At this point, it is essential to emphasize that all these negotiations and discussions are not about whether and when the UK leaves the EU, but how to leave. This focus on the how of leaving has seen a retrospective eruption of interest on the part of both the public and politicians who are actively informing themselves of the core characteristics of the EU: the customs union, single market, agricultural subsidies, environmental standards, and free movement of persons, goods and 
services were never discussed so intensely and in such before the Referendum as they have been in its aftermath.

Although there is an increased contemporary focus on new security risks in a cyber world, very tangible and physical risks still threaten living standards, human rights and our very existence. Cooperation is still an essential prerequisite for combatting such risks. However, cooperation requires agreement on, and adherence to, mutual interests, mutual standards and clear agency. In their contribution to this issue, Jeremy Moulton and James Silverwood discuss the UK's Climate 'actorness' and action in a post-Brexit era. They argue that climate action (and environmental policy in general) lost its impetus well before the referendum and that therefore the future of the UK as a significant actor on climate change does not look very promising. At this point, it is worth questioning whether sidelining or watering down environmental standards and targets might be early indicators of deeper problems of governance. Matilde Ventrella and Ana Isabel Xavier also emphasize the importance of cooperation and the UK's actorness in two specific cases. Matilde Ventrella highlights another malign aspect of wide spread economic disparities: human trafficking. While she investigates how Brexit can affect European cooperation in fighting human trafficking, Ana Xavier explores how Brexit is likely to affect the multilateral structures of international defence and security cooperation.

This is a stressful time for the UK; it is also a stressful time for the EU. In the midst of the migration and refugee crisis, the rise of the far right and deteriorating relations with the US (leading it to the brink of a trade war), Brexit is yet another unwelcome challenge that the EU has to deal with: it is only one of the biggest political issues facing both. It is difficult for the EU to unite its members so that they can deal with a situation and coherently pursue a negotiation they never thought they would be required to engage in. Indeed, the vague formulation of Article 50 is one reason why some, both in the UK and the EU, hope that the referendum result can be overturned or somehow avoided. However, both sides have rather hardened their stances as the period of negotiation has ground on. Each side has its supposedly impassable red lines, lying beyond the possibility of negotiation and constituting its boundaries. Adherents of these red lines have engaged in combat: but it is the EU which seems the most prepared and coherent party in this relentless game. The Brexit timetable is under pressure as a result both of domestic political accidents and turmoil and the EU's rejection of successive UK government plans. The EU has repeatedly warned the UK that a 'pick and mix' approach is not acceptable and that the UK should follow the guidelines set out by the EU. Against this backdrop, Rudi Wurzel casts light on how Brexit appears (from the point of 
view of a leading EU member state, Germany) to be struggling with the twin challenges of European integration and domestic politics.

Some politicians, intellectuals, well known business people, and voters argue for a 'clean' or 'hard' Brexit. Leaving without a deal is not what they fear. In this they have declared their belief in a different future for the UK. Others have a different vision: they are in favour of retaining close ties with the EU even after the UK has ceased to be an EU member state. They stress the importance of maintaining close cooperation with the EU, especially on security and trade matters. On this view, the Norway model (Norway style Brexit) has not surprisingly intermittently featured as a possible solution to the future of EU-UK relations. Those favouring closer ties with the EU see their position vindicated and supported by the rise of USA economic protectionism, strained relations with Russia, global immigrant and refugee crises, increased global terror threats, cyber security risks, lower growth and consumer confidence, and concerns of losing the British way of life. For those of this persuasion a 'No deal Brexit' is unacceptable.

While there is an ongoing argument set forth by Brexiteers that Brexit has not so far produced such bad effects as originally feared (although Brexit has not yet happened), Remainers have already forced the government to take stringent measures on air pollution and on the banning of single use plastics, believing that after Brexit, environmental standards and legislation would be ignored or weakened. Brexiteers, on the other hand, are certain that, following Brexit, the UK will have higher and more stringent environmental standards than the EU. As multinational companies show increasing reluctance to invest in the UK and the Irish border question remains unanswered, the calls for a second referendum and a parliamentary vote on the final deal have also become more and more pronounced. Not surprisingly, perhaps, responses to these issues have created a more hostile and polarised political atmosphere. Remainers accuse Brexiteers and the government of not having a clear strategy for dealing with the negotiations and argue that their incompetence will cost the UK dearly. They argue for the importance of holding a meaningful vote on the final deal agreed by the government and the EU negotiators. On the other side Brexiteers accuse Remainers of hypocrisy and treason. Brexiteer MPs claim that any concessions given to the Remain side would be a betrayal of the "will of people'. Prime Minister, Theresa May, while trying to unite the country and MPs on Brexit in order to have a stronger hand in the negotiations, almost daily faces Tory rebels and rebellions questioning her position. Some warn her of the unworkability and unviability of hard Brexit (particularly because of the intractability of the Irish border problem) while others press her to take a tougher stand claiming that nothing less than hard Brexit is acceptable. 
Not only politicians, but also different economic sectors have expressed their disillusion with the trend of government policy. On the one hand the fishing industry express their disappointment about the terms of transition; on the other hand, the food and creative arts sector warns about the catastrophic impacts of hard Brexit. On top of everything, recent and alarming claims about Russian involvement in the official Leave campaign have also stirred up the political scene.

In all this upheaval, sometimes it seems that the government is edging back to the 'good old days' of the Single Market. However, the irreversible reality of the deeper integration hits all the government plans hard. Numerous British positions were discussed even before the Referendum. Some seems to be plausible with some reservations while others are regarded as impracticable. Regardless of their categorization (such as nightmare, best of the worst, worstsecond best or sensible) with each position and scenario, it becomes clearer and clearer just how all aspects of socio-economic life in the UK have been moulded by EU membership. The Leave campaign's NHS dividend now seems to have disappeared into thin air while voices raising the alarm about the impact of Brexit on the health system and workforce have become louder, more frequent and more insistent. However possible impacts are not limited to the health sector. It is also not limited to concerns about, for example, whether the City would keep its passporting rights in the post-Brexit world - an issue with potentially grave consequences for not only the banking sector but also various other sectors who support and benefit from it. Nevertheless, it is only an important part of a bigger question. The impact is also not exclusively about the fresh food sector either, regardless of how devastating its consequences might be on public welfare and service sector. Rights, responsibilities, standards and rules from which all citizens and the economy have so far benefited and were hitherto taken as granted are now in question: among these we might list pension rights, freedom of movement for British citizens living in other EU countries, air trafficking rules for British passenger planes, research funding opportunities for the Universities, pharmaceuticals research/test and trade, environmental standards, social security rights of EU citizens settled in the UK as well as Britain's global competitiveness and its role in international organisations. The list is long. As can be seen from Ben Duke's contribution, the post Brexit world is unlikely (in the short term at least) to meet the hopes and expectations raised by the proponents of Brexit.

This special issue is not intended to provide a complete catalogue of all Brexit-related developments. That would be impossible. It has no intention of forecasting the outcome of the negotiations either or of trying to chase yesterday's headlines. Rather it has tried to shed light on what the EU (and withdrawal from the EU) means for British politics. The referendum itself has 
already revealed a plethora of kaleidoscopic and self-contradictory visions of the future in the UK which, it is now apparent, have coexisted for a long time. It is important to understand why and how such distinctive and mutually exclusive worldviews have developed in the UK and invaded everyday politics, ultimately leading to the vote to leave the EU. To this end, Rana Izci Connelly concludes this special issue with an indicative overview of the literature on Brexit in order to provide a glimpse into these turbulent times in British politics.

No one is quite sure how the Brexit negotiations will end, nor even how they are being conducted. While the EU requests the UK government to make important and clear-cut decisions, UK proposals seemingly unravel even before they are presented to the EU.

Apparently, the imminence of the issue is not clarifying minds and focusing attention, but amplifying already existing political divisions and revealing the lack of contingency planning. The ruling party and political actors who initiated the Referendum did not seem to worry about the consequences of the vote until it was too late. They seemingly took the view that people do not like risk and uncertainty, that leaving the EU would be perceived as the riskiest and most uncertain option, and that therefore a majority would vote to preserve the status quo of EU membership. However, the Brexit campaign managed to portray continued membership as the riskier and more uncertain decision and hence reversed this equation. Despite warnings about the unpredictability of referendums and the complexity of leaving Europe the dominant view of the time was 'get on with it' combined with an optimistic 'we'll cross that bridge when we come to it'. However, once Brexit negotiations had begun, such lack of vision or, as some argue, 'seeing the issue of leaving the EU through rosetinted spectacles,' has not provided the desired outcomes for anyone. All in all, the question of Europe has always divided political parties, parliament and public opinion in the UK. This time, it also stirred up deep-rooted conflicts and reopened old wounds. At this point, it is important to remember that the holding of referendum, its result and consequences were not only about competing versions of British identity. They reflected a more general populist movement which simultaneously distrusted expertise and the established political order, sought redress of both real and imagined injustices, and believed that there are simple solutions to complex problems. 